\title{
PERLINDUNGAN PEMERINTAH DAERAH TERHADAP KELOMPOK MINORITAS “TOWANI TOLOTANG” DI SULAWESI SELATAN
}

\section{PROTECTION OF LOCAL GOVERNMENT AGAINST "TOWANI TOLOTANG" MINORITY GROUPS IN SOUTH SULAWESI}

\author{
Herman Lawelai \\ Universitas Muhammadiyah Buton, Indonesia \\ E-mail: hermanlawelai@yahoo.com
}

\begin{abstract}
ABSRACT
This article describes the efforts of the regional government to protect the Towani Tolotang people as a minority group in fighting for their identity, the argumentation of justice and group rights in the midst of a pluralistic culture. This article is analyzed with; historical agreements, equal rights, and cultural diversity. Using qualitative research methods, this study found that until now the minority group "Towani Tolotang" still exists in cultural practices as well as in social interactions with the wider community. Relations between communities are supported by local government policy by providing forums that embrace interfaith community leaders, security forces and government elements in fostering community.
\end{abstract}

Keywords: Local Government, Minority Groups, Towani Tolotang

\begin{abstract}
ABSTRAK
Artikel ini menggambarkan upaya pemerintah daerah untuk melindungi masyarakat Towani Tolotang sebagai kelompok minoritas dalam memperjuangkan identitas mereka, argumentasi keadilan dan hak-hak kelompok di tengah-tengah budaya pluralistik. Artikel ini dianalisis dengan; perjanjian sejarah, persamaan hak, dan keanekaragaman budaya. Menggunakan metode penelitian kualitatif, penelitian ini menemukan bahwa sampai sekarang kelompok minoritas "Towani Tolotang" masih ada dalam praktik budaya serta dalam interaksi sosial dengan masyarakat luas. Hubungan antar masyarakat didukung oleh kebijakan pemerintah daerah dengan menyediakan forum yang merangkul tokoh masyarakat lintas agama, pasukan keamanan dan elemen pemerintah dalam membina masyarakat.
\end{abstract}

Kata kunci: Pemerintah Daerah, Kelompok Minoritas, Towani Tolotang

\section{PENDAHULUAN}

Membangun hidup bersama dalam perbedaan secara stabil dan dinamis merupakan tujuan yang ingin dicapai oleh setiap warga negara baik secara individu maupun secara kelompok, begitupun pemerintah manapun dibelahan 
dunia ini termasuk di Indonesia. Berbagai literatur menunjukkan bahwa multikulturalisme di Indonesia sebagai suatu idealisme yang mencita-citakan suatu masyarakat yang hidup bersama secara damai dan tenang. Benyamin Molan menjelaskan bahwa multikulturalisme di Indonesia mempunyai landasan sekaligus sebagai panduan yang jelas dalam Pancasila. Pancasila sebenarnya merupakan upaya para pendiri bangsa (founding fathers) untuk membangun dan menata kewargaan di Indonesia yang prulastik menjadi multikulturalistik (Molan, 2015).

Kesadaran akan pluralitas sebenarnya sudah ada sejak awal. Olehnya itu, sejak awal dilakukan langkah-langkah dalam menghadapi dinamika pluralitas masyarakat Indonesia. Pancasila ditetapkan sebagai dasar negara merupakan gerakan multikulturalistik, hal ini menunjukkan bahwa multikulturalisme sudah dibangun sejak awal ketika ada kesepakatan bangsa ini untuk bersama-sama membentuk sebuah negara. Ketika para founding fathers dalam merumuskan Pancasila, mereka memberi perhatian untuk keadilan bagi setiap warga negara yang ada di indonesia. Kesadaran inilah yang menjadi inspirasi dan rujukan bagi perumusan pembukaan Undang-Undang Dasar (UUD) 1945: “...bahwa sesungguhnya kemerdekaan itu adalah hak segala bangsa dan oleh sebab itu, maka penjajahan di atas dunia harus dihapuskan dan kerena tidak sesuai dengan perikemanusiaan dan perikeadilan" serta Sila ke-Empat: "Keadilan sosial bagi seluruh rakyat indonesia".

Untuk itu, maka keadilan yang berkeadilan bagi seluruh rakyat Indonesia serta ketulusan dalam bertindak adalah kunci kelangsungan multikultur di Indonesia. Negara Kesatuan Republik Indonesia (NKRI) dengan sistem demokrasi dalam memperjuangkan masyarakat yang majemuk. Dengan demikian NKRI akan kuat dan akan tetap terjaga karena tetap besatu, penegakan keadilan oleh negara dalam hal ini pemerintah sangat dibutuhkan. Sebab, keragaman dapat menciptakan gesekan dan benturan antar kelompok masyarakat. Pada sisi lain, kesetaraan dalam pelayanan pada masyarakat beragam sehingga tidak menciptakan kesenjangan yang selanjutnya dapat meminimalisir kecemburuan sosial yang selanjutnya membawa kerawanan sosial. Persatuan harus dikelola sehingga menciptakan iklim yang kondusif untuk kesejahteraan rakyat. 
Namun dalam aplikasinya di lapangan seperti beberapa daerah di Indonesia mendapat fakta yang berbeda. Diskriminasi terhadap kelompok minoritas Tionghoa dalam tragedi 1998 di Jakarta menunjukkan bahwa negara gagal dalam melindungi masyarakat pendatang (Hikmawati, 2017). Pasca orde baru konflik di tingkat lokal masih bergulir diranah hukum seperti operasi perampasan tanah di Karawang yang menggunakan kekuasaan dan lembaga negara (Ananta, 2017). Maraknya sentimen agama dan politik identitas di Indonesia saat ini berada dalam fase kritis (Arjon, 2018).

Dengan demikian negara 'gagal' dalam melindungi identitas budaya masyarakat yang pluralistik. Sehingga mengakibatkan gejolak dari kelompok masyarakat 'yang mendapat diskriminasi' untuk mendapat pengakuan identitas kelompoknya. Pengakuan dan pengelolaan atas kemajemukan di Indonesia 'gagal' dilakukan oleh rezim politik yang berkuasa, maka yang terjadi di lapangan sering kali terjadi pertengkaran, perlawanan, bahkan pemberontakan yang dilakukan oleh komunitas etnis, komunitas agama, maupun komunitas budaya yang hidup dan berkembang dalam lapisan-lapisan masyarakat Indonesia (Qodir, 2014). Memperhatikan penjelasan tersebut maka di Indonesia terdapat dinamika politik dalam kehidupan interaksi sosial masyarakat.

Begitupun pada praktek kewargaan di Kabupaten Sidenreng Rappang (Sidrap), Sulawesi Selatan, terdapat dinamika politik dalam interaksi sosial masyarakat secara umum, dimana tidak dijumpai keadilan bagi setiap warga negara yang beragam saling menghargai dan pengakuan kelompok mayoritas atau saling menerima satu sama lain dalam keberagaman. Secara historis dalam berbagai literatur seperti dikutip dalam (Hasse, 2016), bahwa Kerajaan Sidenreng waktu itu menolak masyarakat selain agama islam tidak boleh menetap di wilayah Sidenreng. Hal ini dibuktikan dengan diskriminasi dalam bentuk kekerasan yang dilakukan pemerintah berkuasa dan elit Islam pada kegiatan ritual keagamaan selain agama Islam (Mudzhar, 2011), begitupun pada saat ini tidak ditemukan tempat ibadah agama selain Islam seperti gereja, pura dan lainnya juga tidak ditemukan.

Secara sosial jumlah penduduk Kabupaten Sidrap berdasarkan data dari dinas kependudukan dan Cacatan Sipil Kabupaten Sidrap pada Desember tahun 2017 
adalah sebesar 325.341 jiwa, sebanyak 161.741 jiwa laki-laki dan 163.600 jiwa perempuan yang terbagi dalam berbagai varian-varian budaya. Sosial budaya masyarakat Sidrap adalah budaya Bugis yang terbagi dalam beberapa kelompok. Kebudayaan Bugis yang biasanya dilakukan aktivitas sosial masyarakat seperti; syukuran setelah panen raya padi (Mappadendang ${ }^{1}$ ), acara pernikahan, dan lain sebagainya, dan tetap berupaya mempertahankan budaya tersebut. Budaya Bugis yang saat ini masih dipertahankan karena masyarakat menganggap warisan dari leluhur yang harus tetap dijaga dan dilestarikan. Menariknya, meski berbeda secara komunitas budaya namun dalam partisipasi politik, dan kegiatan ekonomi bahkan dalam proses pendidikan masyarakat tetap berinteraksi satu sama lain tanpa ada jarak. Komunitas Towani Tolotang misalnya, secara budaya dan keyakinan agama 'bukan Islam' namun tak jarang mereka dijumpai dalam sekolah Islam atau perguruan tinggi Islam.

Adapun kelompok minoritas masyarakat yang menjadi bagian dari warga di Sulawesi Selatan tepatnya di Kabupaten Sidrap adalah kelompok masyarakat Towani Tolotang2. Secara historis kelompok minoritas Towani Tolotang merupakan kelompok yang menganut ajaran kepercayaan 'bukan Islam' yang dibawa oleh Ipabbere ${ }^{3}$. Secara formal mereka mengaku Hindu, meskipun praktekpraktek agama berbeda dengan Hindu pada umumnya (Hasse, 2010). Kepercayaan ini ada sejak abad ke-16 tumbuh dan berkembang di wilayah Kerajaan Wajo (saat ini Kabupaten Wajo), Sulawesi Selatan. Namun karena Islam sudah mulai berkembang rupanya tidak bisa memberi ruang yang bebas untuk berkembangnya bagi Kelompok Towani Tolotang, akhirnya Kelompok Towani Tolong hijrah ke wilayah Kerajaan Sidenreng (saat ini Kabupaten Sidrap) sekitar abad ke-17 untuk mengekspresikan dan mempertahankan keunikan budaya mereka. Setelah dinamika panjang kelompok masyarakat Towani Tolotang berkembang dan diayomi Kerajaan Sidenreng.

${ }_{1}^{1}$ Mappadendang adalah salah satu adat dari suku Bugis. Mappadendang merupakan bentuk syukur atas atas panen padi yang di dapat. Padi yang telah dipanen tadi lalu ditumbuk menggunakan alu dan lesung.

2 Towani Tolotang adalah kelompok masyarakat yang menganut ajaran kepercayaan tingkat lokal yang berpusat di Kabupaten Sidrap.

${ }^{3}$ Sebutan atau nama bagi seorang perempuan telah meniggal sejak ratusan tahun lalu yang membawa ajaran kepercayaan yang dianut oleh kelompok Masyarakat Towani Tolotang hingga saat ini. 
Saat ini terjadi hubungan yang baik antara kelompok atau masyarakat Tolotang dengan warga lainnya dalam aktivitas soial dan politik, hal ini dibuktikan dengan terpilihnya 3 (tiga) orang dari kelompok Towani Tolotang sebagai Anggota Dewan Perwakilan Rakyat Daerah (DPRD) Kabupaten Sidrap. Dengan jumlah penduduk di Kabupaten Sidrap 325.341 jiwa, sebanyak 26.806 jiwa adalah masyarakat Towani Tolotang yang menganut agama Hindu tersebar di Kel. Lotang Benteng di Kec. Maritengngae. Kel. Amparita, Desa Teteaji dan Desa WattaE di Kec. Tellu Limpoe, Kel. Kanyuara di Kec. Sidenreng, Desa Otting dan Desa Dongi di Kec. Pitu Riawa, tetapi basis utamanya berada di Kel. Amparita Kec. Tellu Limpoe.

Secara umum di Kabupaten Sidrap mayoritas masyarakat memeluk agama Islam. Selain itu, juga ada penganut kepercayaan Towani Tolotang yang kemudian menjadi bagian dari agama Hindu dan menjadi kelompok masyarakat yang menganut keyakinan terbanyak kedua setelah kelompok masyarakat yang menganut ajaran Islam. Kemudian ada juga dari agama Kristen, Protestan dan Budha yang jumlahnya tidak seberapa karena hanya dianut oleh masyarakat pendatang yang bermukim di wilayah Sidrap.

Tetapi dalam peristiwa hubungan antara kelompok masyarakat tidak berjalan harmonis seperti pada kota Sorong (Hakim, 2011) dan Poso (Alganih, 2016; Hi Manna \& Kencana Syafiie, 2014). Sepeti halnya masyarakat majemuk di negara lain seperti kelompok minoritas Muslim Rohingya di Negara Myanmar berbanding terbalik apa yang terjadi di Kabupaten Sidrap saat ini. Meskipun mereka masyarakat pendatang menurut sejarahnya, (Kipgen, 2014) seperti halnya masyarakat Towani Tolotang secara historis. Namun dalam prakteknya kelompok minoritas Muslim Rohingya tidak diterima oleh masyarakat secara umum dalam 'interaksi sosial' di negara Miyanmar. Bahkan, kelompok minoritas Muslim Rohingya mendapat perlakuan yang tidak berkeadilan dengan kekerasan secara berlebihan seperti pembunuhan, pembakaran rumah dan tempat ibadah muslim yang dilakukan oleh masyarakat mayoritas (Kipgen, 2014).

Dalam situasi demikian, agama seringkali muncul sebagai faktor konflik dalam masyarakat yang berakal dari keberagaman, seperti yang terjadi pada kasus bentrokan antar komunitas agama Hindu dan komunitas Muslim di India yang banyak menelan korban manusia (Pulungan, 2018). Pada kasus tersebut menjadi 
bahan pembelajaran penting untuk melihat perspektif keberagaman di Indonesia yang hidup dalam sosiologis-politik pluralistik, yang beragam argumentasi pada identitas politik kelompok minoritas. Begitupun analisis pada tindakan politis dalam rangka mengedepankan kepentingan-kepentingan dari anggota-anggota suatu kelompok karena memiliki kesamaan identitas atau karakteristik, baik berbasiskan pada ras, etnisitas, jender, atau keagamaan (Douglass, 2017).

Mengamati dinamika yang terjadi di tengah masyarakat menjadi sebuah masalah sebab kegiatan yang dilakuakan cenderung merusak dan dan memakan korban jiwa. Dinamika tersebut merupakan sebuah tantangan pemerintah dengan menciptakan dan menetapkan "Institutionalisation of Conflict" (termasuk didalamnya cara-cara "Managemen of Conflict" (Jumadi, 2016). Dinamika yang terjadi di tengah masyarakat harus diidentifikasi, di cari sebabnya dan ada upaya untuk menghilangkan permasalahan yang terjadi di tengah masyarakat. Dengan demikian maka kebijakan pemerintah baik secara lokal maupun nasional sangat dibutuhkan pada bagian penataan kewargaan yang multikultur.

Hubungan antara adat dengan Islam, dan belakangan antara adat, Islam dan negara bervariasi sepanjang sejarah (Rozi, 2013). Membangun relasi serta menjalin komunikasi yang baik antara kelompok atau golongan masyarakat yang ada tanpa membedakan antara satu dengan yang lain, sehingga asas kesamaan hak sebagai warga negara dapat terwujud. Kemampuan pemerintah untuk tanggap (responsive) terhadap dinamika permasalahan yang berkembang ditengah masyarakat, sehingga para pemangku kebijakan, bisa merumuskan strategi yang tepat dalam menjamin kepentingan umum melalui pelayanan publik untuk mengakomodir kepentingan pada ras, etnisitas, jender, atau keagamaan yang melekat pada masyarakat (Maarif, 2012).

Sehingga praktek kewargaan multikultur di Kabupaten Sidrap pada kajian komunitas Towani Tolotang menjadi menarik untuk dianalisis bahwa, bagaimana perlindungan pemerintah daerah tehadap kelompok minoritas "Towani Tolotang" di Kabupaten Sidrap, Sulawesi Selatan? karena mereka dikenal sebagai kelompok yang minoritas sekaligus masyarakat pendatang berdasarkan sejarah. Hingga saat ini, terdapat satu konsensus di kalangan masyarakat Kabupaten Sidrap bahwa "selain Islam (Muslim); tidak diperbolehkan hidup menetap di wilayah ini". 
Sedangakan mayarakat Towani Tolotang adalah bukan Islam. Akan tetapi, mereka dapat hidup, diterima dan berkembang sampai saat ini di Kabupaten Sidrap.

\section{METODE PENELITIAN}

Artikel ini adalalah hasil penelitian lapangan, penulis menggunakan pendekatan penelitian deskriptif kualitatif. Karena menurut (Moleong, 2012) penelitian kualitatif merupakan pemahaman tentang fenomena yang sedang dialami oleh subyek penelitian baik secara holistik ataupun dengan cara memanfaatkan berbagai metode alamiah. Pada artikel ini, penulis menggunakan pendekatan studi kasus yang dimulai dengan mengidentifikasi satu kasus yang spesifik seperti kasus berupa entitas yang kongkret misalnya, individu, komunitas kecil, organisasi, atau kemitraan (Creswell, 2014) Sehingga fenomena terhadap dinamika politik multikulturalisme sangat mendukung peneliti untuk melakukan penelitian dengan metode kualitatif berdasarkan karakteristik penelitian dilapangan.

Adapun pertimbangan penulis memilih Sulawesi Selatan tepatnya di Kabupaten Sidrap sebab, dari segi fokus penelitian yang ingin ditulis sangat relevan dengan permasalahan yang ada karena menyangkut antara negara dan masyarakat, dimana negara hadir memberikan perlindungan kepada seluruh rakyat tanpa memandang suku, etnis, ras, agama dan lain sebagainya yang juga merupakan kajian studi ilmu politik dan pemerintahan. Kedua, Kabupaten Sidrap merupakan pusat atau daerah dimana komunitas Towani Tolotang berkembang dan berinteraksi dengan masyarakat lain secara terbuka.

\section{HASIL DAN DISKUSI}

Kajian multikultur tentang hak-hak kewarganegaraan, sebagai respons atas kesalahan dan kegagalan liberalisme dan juga demokrasi dinilai telah melakukan kesalahan fatal dengan mengabaikan kelompok-kelompok minoritas bangsa dan komunitas di dalam satu negara atau bangsa mayoritas dan di tengah pluralitas kebudayaan yang ada (Kymlicka, 2018). Will Kimlicka menjelaskan bahwa dinamika yang melekat dalam kewarganegaraan majemuk di bagian Asia memiliki 
hubungan yang erat dengan barat yang menjadi tantangan dalam tradisi sosial masyarakat (Kymlicka, 2018). Seperti halnya yang terjadi di negara Indonesia dalam praktek masyarakat majemuk di Kabupaten Sidrap Sulawesi Selatan, dimana kelompok mayoritas pada awalnya menolak kelompok Towani Tolotang (Hasse, 2016), sebelum ada konsensus yang memperjuangkan keadilan dan hak kewargaan bagi komunitas Towani Tolotang. Secara umum realitas yang terjadi adalah 'dominasi budaya mayoritas' terhadap minoritas.

Akses pada kebudayaan kemasyarakatan merupakan sebuah urgensi bagi kebebasan individu. Sebagian besar masyarakat memiliki kaitan yang erat dengan kebudayaannya sendiri, juga mereka mempunyai kepentingan yang sah dalam mempertahankan ikatan dengan budaya mereka. Kaum liberal percaya bahwa kepentingan masyarakat dalam keanggotaan pada suatu kebudayaan yang dilindungi secara memadai oleh hak-hak bersama kewargaan, dan bahwa kebijakan selanjutnya untuk melindungi kepentingan itu tidak sah. Mereka mengatakan bahwa suatu sistem hak-hak universal individu sudah mengakomodasi perbdaan budaya, dengan memberikan kepada setiap orang kebebasan berserikat dengan orang-orang lain dalam melanjutkan praktekpraktek keagamaan atau budaya budaya bersama. Kebebasan berserikat memungkinkan orang dari berbagai latar belakang untuk melanjutkan hidup yang berbeda tanpa ada interferensi.

Kymlicka (Kymlicka, 2018) mengajukan tiga argumen dalam rangka membela kebijakan-kebijakan terhadap kelompok minortas: Kesetaraan, Kesepakatan Sejarah dan Nilai Keragaman Budaya demi menciptakan keadilan dan hak-hak minoritas. Pada kajian ini peneliti menganalisis kebijakan pemerintah daerah dalam melindungi budaya Towani Tolotang di kabupaten sidrap, secara rinci dibagi dalam beberapa dimensi antara lain; kesepakatan sejarah, kesetaraan dan nilai keragaman.

\section{Kontrak Kesepakatan Antara Pemerintah dan Kelompok Towani Tolotang}

Pada dimensi ini yang diukur adalah bentuk perjanjian sejarah antara pemerintah daerah dengan masyarakat Towani Tolotang. Ada berbagai bentuk perlakuan diskriminasi yang dilakukan oleh pemerintah yang berkuasa maupun 
masyarakat Islam sebagai kelompok mayoritas terhadap kelompok masyarakat Towani Tolotang di kabupaten Sidrap pada awal kedatangan mereka dari Kerajaan Wajo sekitar tahun 1666, sebab Islam di wilayah Wajo sudah berkembang sehingga membatasi praktek budaya maupun ajaran kepercayaan Towani Tolotang (Mudzhar, 2011).

Bentuk diskriminasi dari pemerintah pada saat itu adalah Raja Sidenreng mengelurkan fatwa "selain masyarakat Islam tidak boleh tinggal menetap untuk bermukim di wilayah Sidenreng". Sedangkan diskriminasi yang dilakukan oleh masyarakat Islam dalam bentuk melakukan tindakan untuk menghalangi praktek ajaran kepercayaan Towani Tolotang karena mereka beranggapan bahwa praktek tersebut adalah "ajaran yang sesat" karena menyembah tempat keramat atau mempersembahkan sesajen, kuburan dan "Posi' Bola".

Komunitas Towani Tolotang meski mendapat penolakan dari masyarakat pada akhirnya melakukan pendekatan kepada La patiroi Addatuang Sidenreng VII sebagai raja sidenreng untuk meminta diberikan izin untuk bernaung di wilayah Sidenreng. Atas tindakan tersebut raja sidenreng mengeluarkan kebijakan disebabkan baginda raja mengetahui maksud kedatangan Towani Tolotang dan mengizinkan untuk tinggal di wilayah Sidenreng dengan beberapa persyaratan yang dituangkan dalam surat perjanjian "Ade Mappurna Onrong Sidenreng" (Mudzhar, 2011). Pokok-pokok isi perjanjian itu ialah sebagai berikut:

1. Ade Mappure OnroE (Adat Sidenreng tetap utuh dan harus dipatuhi).

2. Warialatutui (Keputusan harus dipelihara baik).

3. Janci Ripiasseri (Janji harus ditepati).

4. Rapang Ripannennungeng (Suatu keputusan yang telah berlaku harus dilanjutkan).

5. Agama Ritanree Maberre (Agama Islam harus diagungkan dan dijalankan)

Secara khusus persyaratan kelima untuk pelaksanaan syariat Islam seperti shalat, puasa dan lain sebagainya ditunda kecuali dalam dua hal yaitu perkawinan dan kematian.

Pihak rombongan pengungsi menerima kesepakatan tersebut. Mereka tinggal di suatu tempat, $3 \mathrm{~km}$ sebelah selatan Amparita. Di tempat tersebut sangat susah memperoleh air sehingga tempat itu diberi nama "Loka Pappang" yang 
berarti susah dan lapar. Setelah mereka mengolah tanah dan mulai berhasil bercocok tanam hingga mereka merasakan hidup nyaman, akhirnya nama tempat tinggal mereka diganti dari Loka Pappang menjadi Parrinyameng yang berarti susah dan senang, dengan maksud setelah kesusahan datanglah kesenangan. Di tempat inilah tokoh masyarakat Towani Tolotang I Pabbere meninggal dunia dan dikuburkan dan kuburan tersebut pulalah yang menjadi sentral persembahan tahunan bagi masyarakat Towani Tolotang.

Setelah beberapa tahun tinggal di Perrinyameng, Raja Sidenreng menyerahkan permasalahan masyarakat Towani Tolotang kepada Arung Amparita. Oleh Arung Amparita lalu mereka diperintahkan untuk meninggalkan wilayah Perrinyameng untuk kemudian tinggal di perkampungan Amparita bersama masyarakat asli. Atas kebijakan dan perintah Arung Amparita tersebut kelompok masyarakat Towani Tolotang meninggalkan wilayah Perrinyameng untuk bergabung serta berbaur dengan masyarakat Amparita, dari sinilah awalnya interaksi secara sosial terjadi secara lansung antara masyarakat Amparita yang notabene 'masyarakat Islam' dengan kelompok masyarakat Towani Tolotang. Atas kebijakan ini jugalah sebagai cikal-bakal mereka untuk berdiaspora ke berbagai wilayah kerajaan Sidenreng.

Sesuai perjanjian sebelumnya syariat Islam dilakukan oleh masyarakat Towani Tolotang dalam hal perkawinan dan kematian dibawah binaan Imam Amparita, aturan ini dilaksanakan dari awal kedatangan mereka sekitar tahun 1666 sampai tahun 1944. Pada tahun 1944 pemerintah penjajah jepang mengelurkan kebijakan pelarangan kepada mereka yang tidak melaksanakan ibadah shalat secara syariat Islam, tidak boleh pada acara kematian dan pernikahan mengunakan syariat Islam (Mudzhar, 2011). Atas kebijakan tersebut K.H. Muin Yusuf selaku Qadi Sidenreng waktu itu menerusakan kebijakan tersebut kepada Imam Amparita La Palinge untuk dilaksanakan. Sejak saat itulah acara perkawinan dan kematian bagi masyarakat Towani Tolotang dilaksanakan menurut kepercayaan mereka sendiri, atau tidak lagi menggunakan syariat Islam hingga saat ini.

Acara perkawinan atau pernikahan masyarakat Towani Tolotang dilaksanakan sama seperti perkawinan etnis bugis secara umum. Adapun yang 
sangat membedakan ialah dalam hal rukun nikah, sebab bagi meraka baru memandangnya syah apabila dilakukan oleh dan dihadapan Uwa'ta, setelah kedua pihak menyetujuinya dan terdapat dua orang saksi. Apabilah kedua dahi dipegang oleh uwa'ta dan keduanya dimasukkan dalam sarung, berati sudah syahlah perkawinan tersebut. Begitupun dalam proses perceraian harus seizin Uwa'ta, sepasang suami isteri yang tidak hidup rukun lagi maka mereka melaporkan kepada Uwa'ta. Apabila Uwa'ta telah mengetahui dan mempertimbangkan persoalannya, maka diputuskanlah bercerai atau tidaknya pasangan suami tersebut. Wanita yang baru saja diceraikan dapat menikah kembali dengan lakilaki yang disukainya tanpa masa iddah (masa menunggu).

Secara administratif akta perkawinan dan perceraian Towani Tolotang dicatat pada Kantor Pencatatan Sipil Kabupaten Sidrap sejak berlakunya UU Perkawinan No.I/1974 beserta peraturannya, dan berjalan hingga saat ini. Sebelumya seperti yang telah dijelaskan tersebut sejak zaman kemerdekaan, perkawinan tidak pernah dicatat baik oleh Kantor Pencatatan Sipil maupun Kantor Urusan Agama (KUA). Hal tersebut dikarenakan sejak tahun 1944, mereka melakukan perkawinan dengan tata cara mereka sendiri, sehingga tidak dicatat oleh KUA. Pada masa sebelum itu, sejak kedatangan nenek moyang mereka dari Wajo pada tahun 1966 sampai tahun 1944, sesuai dengan perjanjian mereka dengan raja Sidenreng bahwa meraka harus kawin sesuai dengan syariat Islam (Mudzhar, 2011).

Dalam hal kematian atau penyelenggaraan mayat juga dilaksanakan secara adat Towani Tolotang. Mayat mayat didudukkan dan dimandikan di dalam rumah. Apabila mayat tersebut adalah Uwa', beliau dimadikan sambil dipangku secara berhadapan oleh beberapa orang keluarganya. Setelah dibaringkan kembali, mayat dibungkus kain putih yang dilapisi daun siri dari dalam. Pada bagian tertentu daun siri ditambahkan lebih banyak, hal ini dilakuakan agar mayat cepat diterima oleh Dewata SewwaE. Di dalam kubur mayat dibaringkan menghadap ke barat dan kepala si sebelah utara. Di bawah batu nisan yang baru ditanam dilapisi beberapa daun siri dan tiga buah pinang yang dibungkus daun pisang. 


\section{Prinsip Kesetaraan dalam Pelayanan Publik}

Pada dimensi ini yang diukur adalah bentuk perlakuan yang sama bagi setiap warga negara secara adil dan merata tanpa memandang etnis, suku dan agama di Kabupaten Sidrap. Kebijakan pemerintah dalam bentuk pelayan publik atau bentuk perlakuan kepada masyarakat yang dilakukan tanpa ada perbedaan atau perlakuan khusus antara kelompok masyarakat, begitupun dengan kelompok masyarakat Towani Tolotang meskipun terdapat perbedaan dalam praktek budaya dengan masyarakat Islam sebagai kelompok mayoritas di Kabupaten Sidenreng Rappang. Adanya persamaan hak antara kelompok masyarakat yang dijamin oleh konstitusi dapat tercipta di Sidrap selama ini, salah satunya yaitu adanya visi pemerintah dalam meningkatkan perekonomian masyarakat yang sebagian besar adalah petani.

Salah satu program pertanian yang cukup menonjol dalam meningkatkan perekonomian masyarakat yakni penyediaan dana talangan oleh pemerintah daerah sebesar Rp. 2 milyar di setiap musim tanam (Asnawi \& Madjulekka, 2017). Dana talangan digunakan untuk pengadaan pupuk bagi petani padi sawah, melalui kerja sama dengan salah satu perusahan pupuk nasional. Dengan dana tersebut diharapkan dapat meminimalisir persoalan ketersediaan pupuk pada saat musim tanam, sebab sebelum musim tanam berjalan, pupuk sudah tersedia untuk musim tanam berikutnya. Kebijakan pemerintah daerah tersebut untuk mencapai target produksi padi sebesar 533 ton per tahun.

\section{Grafik1.}

\section{Produksi Padi Sidrap 2014-2017}

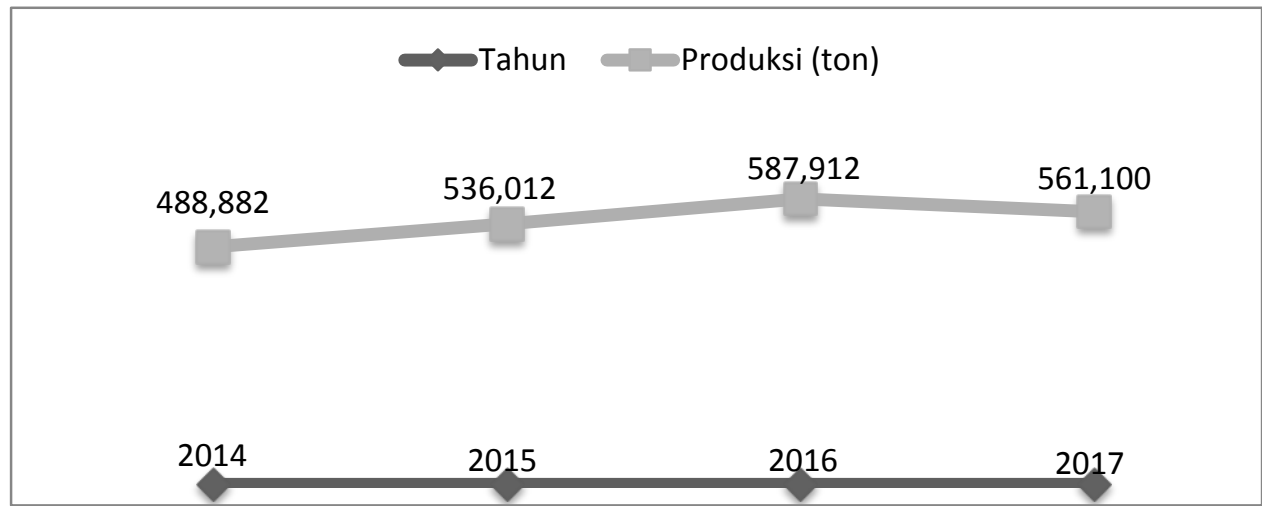

Sumber: diolah penulis 
Hal ini dapat dilihat dari proses retribusi pelayanan publik dalam mendapatkan bantuan raskin, alat pertanian dan lain-lain. Seperti yang dijelaskan oleh Lurah Lakessi, Bapak Arisal Arsad bahwa:

"Kami sebagai pemerintah dalam melakukan pelayanan publik di lingkungan Kelurahan Lakessi, kami tidak membeda-bedakan masyarakat mayoritas dengan minoritas dalam hal ini masyarakat Islam dengan Towani Tolotang, bahkan bantuan yang kami berikan kepada masyarakat Towani Tolotang justru lebih banyak mendapatkan bantuan pertanian dibandingkan dengan masyarakat muslim, sebab Towani Tolotang di wilayah kami rata-rata adalah petani sawah." (data wawancara)

Hal ini mendapat tanggapan yang sama dari Uwa' Palimai yang merupakan Tokoh Masyarakat Towawani Tolotang di Kelurahan Lakessi, mengatakan bahwa:

"Selama ini kami mendapat perlakuan yang sama dengan masyarakat lainnya di Kabupaten Sidrap. Mulai dari pelayanan di tingkat Desa/Kelurahan, Kecamatan hingga di tingkat lingkungan SKPD Kabupaten Sidrap, utamanya pelayanan pendidikan dan kesehatan". (data wawancara)

Dari penjelasan tersebut menggambarkan bahwa kesetaraan bagi setiap warga negara di Kabupaten Sidrap tercipta dari pelayanan publik oleh pemerintah daerah. Hal ini dilakukan untuk menciptakan keadilan dalam pelayanan publik sesuai amanat UU yang berlaku yang diemban olah Aparatur Sipil Negara. Selain itu pada pelayanan pada tingkat kecamatan Seperti yang telah dijelaskan sebelumnya bahwa Kabupaten Sidrap adalah sebuah daerah yang mayoritas masyarakatnya adalah petani. Perkembangan ekonomi pertanian masyarakat selama ini merupakan upaya pemerintah daerah dalam meningkatkan perekonomian masyarakat sidrap.

Begitupun di Amprita Kecamatan Tellu LimpoE sebagai basis utama secara populasi terbesar masyarakat Towani Tolotang di kabupaten Sidrap. Pelayanan publik yang dilakukan oleh pemerintah setempat juga menggunakan asas kesetaraan. Kesetaraan dalam hal distribusi bantuan terhadap masyarakat, salah satunya batuan subsidi pupuk. Pupuk bersubsidi diberikan pemerintah tanpa membedakan antara masyarakat muslim dan masyarakat Towani Tolotang. Camat Tellu LimpoE, Muhammad Asrul menjelaskan bahwa:

"Dalam melakukan pelayanan kepada masyarakat, kami tidak membedakan anrata kelompok masyarakat, kami berikan pelayanan secara prima serta 
memberikan bantuan secara merata kepada masyarakat." (data wawancara)

Praktek kesetaraan dalam kehidupan bermasyarakat di Kabupaten Sidenreng Rappang dapat dilihat dari kebijakan pemerintah daerah dalam memberikan pelayanan kepada masyarakat yang multi-budaya tanpa memandang etnis, suku dan agama. Hal ini dilakukan untuk memastikan bahwa setiap warga negara mendapat perlakuan dan hak yang sama dalam mendapatkan layanan dari pemerintah daerah. Layanan pemerintah daerah tersebut seperti pendidikan dan kesehatan gratis yang dilaksanakan pemerintah daerah Kabupaten Sidenreng Rappang sejak tahun 2008. Pendidikan gratis mulai tingkat SD sampai pada tingkat SMA yang dilaksanakan di seluruh sekolah di Kabupaten Sidenreng Rappang. Begitupun layanan kesehatan gratis bagi setiap masyarakat Kabupaten Sidenreng Rappang mulai pada tingkat Pustu di desa/kelurahan, Puskesmas di tingkat kecamatan sampai pada tingkat kabupaten di RSUD Nene' Mallomo hanya dengan memperlihatkan Kartu Tanda Penduduk (KTP) dan Kartu Keluarga (KK).

Salah satu pelayanan kesehatan di Sidrap adalah terobosan memangkas birokrasi dalam pelayanan kesehatan geratis. Jika warga lain di sebagian daerah Sulawesi Selatan harus membayar premi BPJS kesehatan sebagai dasar pengobatan gratis pada Puskesmas dan Rumah Sakit. Menariknya, di Kabupaten Sidrap, masyarakat cukup memperlihatkan KTP dan KK di Puskesmas dan Rumah Sakit, maka sudah mendapat pelayanan kesehatan dan pengobatan gratis. Kebijakan ini sebagai respon terhadap kebanyakan masyarakat dipusingkan dengan sistem pelayanan kesehatan gratis dengan merujuk mekanisme BPJS kesehatan yang kadang cukup ribet. Belum lagi pembayaran premi per bulan yang cukup membebani masyarakat, terutama bagi warga kurang mampu. Padahal, masyarakat yang sakit perlu mendapat pelayanan kesehatan dengan cepat, tanpa birokrasi yang rumit. Sekertaris daerah, sudirman Bungi menjelaskan:

"Kesehatan gratis sejak dua tahun lalu sudah dihapus oleh Pemprov. Sulsel. Hanya di wilayah Sidrap program kesehatan gratis ini tetap dijalankan. Siapapun, cukpup KTP dan KK saja diperlihatkan, warga sudah menikmati kesehatan gratis" (data wawancara). 


\section{Nilai Keragaman Budaya}

Pada dimensi ini yang diukur adalah manfaat dari nilai keragaman budaya yang terjadi di wilayah Sidenreng Rappang. Pemerintah daerah Sidrap, setelah keluarnya surat keputusan pemerintah pusat melalui Dirjen Bimas Hindu/Budha yang melindungi Towani Tolotang sebagai bagian dari sekte agama Hindu. Kebijakan pemerintah pusat tersebut membuat pemerintah daerah Kabupaten Sidrap mengakomodir masyarakat Towani Tolotang sebab di Indonesia mengakui sejumlah "agama resmi" salah satunya adalah agam Hindu. Sehingga, apabila pemerintah daerah Kabupaten Sidrap tidak mengakomodir dan memberikan hakhak suatu kelompok masyarakat di dalam wilayahnya, secara tidak langsung pemerintah Kabupaten Sidrap telah melanggar konstitusi. Sehingga tindakan tersebut sebagai bentuk akomodatif menciptakan keragaman budaya masyarakat.

Bentuk akomodatif politik Towani Tolotang yang dilakukan pemerintah Kabupaten Sidrap yaitu dengan memberikan kesempatan kepada masyarakat Towani Tolotang untuk berpartisipasi dalam setiap pemilu yang diselenggarakan. Partisipasi politik mulai dari Pilkades, Pileg dan Pilkada yang telah diberikan baik dalam bentuk pemilih maupun dipilih sebagai calon. Begitupun dalam posisi pemerintahan dilingkup Aparatur Sipil Negara (ASN) sebagai PNS, masyarakat Towani Tolotang diberikan kesempatan yang sama seperti halnya kelompok masyarakat lainnya di Kabupaten Sidrap. Sebab, masyarakat Towani Tolotang memiliki kekuatan budaya sebagai alasan pemerintah untuk mempertahan kelompok mereka di Kabupaten Sidrap.

Kekuatan budaya Towani Tolotang adalah persatuan mereka yang tetap terjaga. Budaya tersebut dapat dijelaskan dalam 2 hal yaitu; budaya keagamaan dan budaya dalam akativitas sosial. Kekuatan budaya keagamaan seperti; kegiatan wajib tahunan adalah berkumpul (Sipulung) dengan maksud, berkumpul bersama yang dilaksanakan setahun sekali sebagai hari raya, yang dihadiri ribuan warga Towani Tolotang di dalam maupun di luar Kabupaten Sidrap yang datang berbondong-bondong dengan berjalan kaki (tanpa menggunakan alas kaki bagi masyarakat biasa), sedangkan Uwa' atau pemangku adat dan tokoh Towani Tolotang menggunakan kuda yang di pandu oleh masyarakat. Mereka berkumpul 
di Parinyameng untuk melakukan ritual keagaamaan dan memotong kerbau dan sapi untuk persembahan kepada kuburan leluhur mereka I Pabbere.

Kegiatan keagamaan selanjutnya, penganut kepercayaan Towani Tolotang mengadakan saji-sajian atau Mola Laleng sebagai bekal, dengan cara Mappenre Inanre yaitu mengantarkan sesajen kepada Uwa' yaitu pemimpin mereka berupa nasi beserta lauk-pauknya. Hal ini mereka lakukan apabila ada acara perkawinan, kelahiran, kematian, atau memperoleh sesuatu keberhasilan dan untuk pahala kemudian hari. Selanjutnya, mereka melakukan Tudang Sipulung yaitu duduk berkumpul untuk melakukan acara ritual tertentu guna memohon doa keselamatan bersama, seperti memohon hujan karena kemarau panjang terjadi, sedangkan musim tanam di sawah telah tiba, dan lain-lain. Acara ritual tersebut dilakuan pada malam hari dan dilanjutkan dengan pawai keliling kampung.

Sedangkan budaya dalam aktivitas sehari-hari, masyarakat Towani Tolotang akomodatif menerima perkembangan zaman tanpa meninggalkan ciri khas mereka seperti yang dijelaskan sebelumnya. Bentuk akomodatif tersebut, seperti dalam berpakaian dan penggunaan alat elektronik. Begitupun dalam membangun relasi (secara politik, pemerintahan dan aktivitas sosial) masyarakat Towani Tolotang ikut serta dalam melaksanakan ritual keagamaan Islam sebagai penghormatan kepada umat muslim, seperti menggunakan hijab serta berpartisipasi dalam maulid nabi Muhammad Saw. yang dilaksanakan di sekolah tempat mereka menuntut ilmu pengetahuan.

Atas tindakan masyarakat Towani Tolotang tersebut baik dalam budaya keagamaan maupun dalam aktivitas sosial sehingga pemerintah daerah mengakomodir mereka dan diberiakan kebebasan secara kultural bentuk akomodatif pemerintah Kabupaten Sidrap terhadap Towani Tolotang dilakukan dengan memberikan kesempatan untuk mengekspresikan kebudayaan Towani Tolotang seperti halnya masyarakat lainnya. Masyarakat Sidrap berjumlah 325.341 jiwa, yang terbagi dalam berbagai varian-varian budaya.

Pada umumnya budaya masyarakat Sidrap terbagi dalam beberapa kelompok, yang tetap berinteraksi antara satu sama lain. Interaksi terjadi sebab, pemerintah daerah melindungi kebebasan yang dijamin dalam konstitusi, agar masyarakat tetap berekspresi dan menjalankan budaya mereka dengan beberapa 
pengecualian, senantiasa harus menjaga keamanan, ketentraman dan ketertiban umum masyarakat. Setiap kegiatan budaya yang melibatkan banyak masyarakat dilaksanakan atas sepengetahuan pemerintah setempat dan harus mendapat surat izin keramaian dari pihak keamanan dalam hal ini adalah kepolisian. Sekretaris Daerah Sidrap, Sudirman Bungi mengatakan:

"sebagai pemerintah daerah kami senantiasa mengingatkan kepada masyarakat untuk senantiasa menjaga keamanan, ketentraman dan ketertiban umum dalam kehidupan bermasyarakat." (data wawancara)

Disaat berada dalam lingkungan masyarakat secara tidak langsung masyarakat bukan hanya dari satu golongan atau budaya saja, akan tetapi berbagai macam budaya (bahasa, gaya hidup, keyakinan, dan lain sebagainya). Kebijakan dalam membangun pola pikir masyarakat dalam berinteraksi sangat diperlukan, dimana masyarakat walaupun berbeda akan tetapi memiliki hak dan kesempatan yang sama sebagai masyarakat, tanpa melihat perbedaan yang ada. Pentingnya pemerintah untuk mengerti dan paham mengenai budaya masyarakat diperlukan untuk memahami karakter masyarakat. Yang paling penting adalah dengan adanya perbedaan perlu dipahami dan diterima dengan sebaik-baiknya agar toleransi masyarakat terwujud dengan hidup rukun berdampingan tanpa melihat unsur yang berbeda.

Komunitas Towani Tolotang dalam interaksi sosial masyarakat senantiasa memperhatikan nilai-nilai sosial mereka. Nilai-nilai sosial budaya mereka berbeda dengan masyarakat Sidrap secara umum. Perbedaan terlihat pada kesederhanaan mereka yang senantiasa mereka junjung tinggi. "Sebahagian" masyarakat Sidrap dalam kategori sejahtera dapat terlihat pada model rumah yang bertingkat dan terlihat bagus. Menariknya masyarakat Towani Tolotang meski sejahtera namun rumahnya hanya terbuat dari kayu dan tidak memiliki dinding yang terbuat dari cermin, bahkan tak jarang dijumpai dinding rumah mereka terbuat dari anyaman daun kelapa atau bambu, begitupun dengan gaya berpakaian maupun dalam gaya mereka dalam interaksi. Meski, rumah masyarakat Towani Tolotang tidak tertata dengan baik. Nilai-nilai kebudayaan Towani Tolotang didasarkan pada penafsiran mereka mehami ajaran keyakinan yang mereka anut selama ini. 
Pemerintah dengan kewenangan otonomi daerah yang memberi peluang bagi daerah untuk berkembang seluas mungkin. Otonomi daerah memungkinkan setiap daerah menonjolkan kekhasan nilai budaya sebagai sumber potensi. Namun di sisi lain, era otonomi daerah yang dijamin konstitusi tidak dimanfaatkan oleh pemerintah dalam mengembangkan nilai budaya masyarakat Towani Tolotang. Nilai dari kebudayaan menjadi salah satu alasan wisatawan untuk berkunjung ke suatu daerah. Nilai kebudayaan Towani Tolotang sangat potensial untuk dijadikan sebagai sektor pawisata baru di Kabupaten Sidrap.

Saat ini dengan pemukiman masyarakat Towani Tolotang tidak tertata dengan baik, sehingga diharapkan kebijakan pemerintah dalam menata pemukiman Towani Tolotang agar terlihat rapi, tanpa mengurangi nilai kesederhanaan sebagai nilai keragaman. Kebijakan ini diperlukan dengan mempertimbangkan wisatawan kebudayaan saat ini menjadi tujuan bagi wisatawan regional, nasional bahkan internasional. Untuk mewujudkan hal tersebut, pemerintah Sidrap dengan kewenangan otonom, sangat diperlukan untk menentukan kebijakan yang berhubungan dengan daya saing, promosi wisata, dan nilai tambah. Misalnya, pemerintah menata tampilan depan rumah warga yang berada di lingkungan Towani Tolotang sebagai objek parawisata dengan nuansa daerah setempat.

\section{KESIMPULAN}

Dari temuan dan analis tersebut maka dalam penelitian ini dapat disimpulkan bahwa, kelompok masyarakat Towani Tolotang di Kabupaten Sidrap hingga saat ini tetap eksis dalam praktek budaya maupun dalam interaksi sosial dengan masyarakat sidrap secara umum dibarengi dengan kebijakan yang dilakukan oleh pemerintah daerah terhadap Towani Tolotang di Kabupaten Sidrap, dalam penelitian ini membuktikan bahwa:

Secara kontrak sosial antara Towani Tolotang dengan pemerintah daerah diawal kedatangannya disepakati beberapa hal yang dituangkan dalam surat perjanjian "Ade Mappurna Onrong Sidenreng”. Pokok-pokok isi perjanjian itu ialah sebagai berikut: Pertama, Ade Mappure OnroE (Adat Sidenreng tetap utuh dan harus dipatuhi). Kedua, 
Warialatutui (Keputusan harus dipelihara baik). Ketiga, Janci Ripiasseri (Janji harus ditepati). Keempat, Rapang Ripannennungeng (Suatu keputusan yang telah berlaku harus dilanjutkan). Kelima, Agama Ritanree Maberre (Agama Islam harus diagungkan dan dijalankan). Secara khusus persyaratan kelima untuk pelaksanaan syariat Islam seperti shalat, puasa dan lain sebagainya ditunda kecuali dalam dua hal yaitu perkawinan dan kematian.

Secara dimensi kesetaraan dalam penelitian ini menemukan bahwa saat ini antara kelompok masyarakat di Kabupaten Sidrap diperlakukan secara adil dan merata. Begitupun dengan komunitas Towani Tolotang meski di awal kedatangannya mendapat perlakuan tidak adil oleh pemerintah, namun saat ini Towani Tolotang sudah mendapat kebijakan pelayanan yang dilakukan oleh pemerintah daerah seperti, distribusi bantuan pertanian, pendidikan dan kesehatan gratis sama halnya dengan masyarakat Sidrap yang lain.

Secara dimensi nilai keragaman budaya dalam penelitian ini ditemukan bahwa, pemerintah daerah belum membuat kebijakan terhadap kebudayaan yang ada di Kabupaten Sidrap. Begitupun dengan, Towani Tolotang yang kental dengan keunikan budayanya. Keunikan nilai budaya Towani Tolotang potensial untuk dikembangkan menjadi sektor parawisata baru di Kabupaten Sidrap. Untuk mewujudkan hal tersebut, pemerintah Sidrap dengan kewenangan otonom untuk menentukan kebijakan yang berhubungan dengan daya saing, promosi wisata, dan nilai tambah. Sehingga dengan adanya kebijakan tersebut sektor parawisata mampu menciptakan lapangan baru dan dinikmati masyarakat setempat.

\section{REFRENSI}

Alganih, I. (2016). Konflik Poso (Kajian Historis Tahun 1998-2001). Criksetra: Jurnal Pendidikan Sejarah, 5(2), 166-174. https://doi.org/10.36706/JC.V5I2.4814

Ananta, D. D. (2017). Politik Oligarki dan Perampasan Tanah di Indonesia: Kasus Perampasan Tanah di Kabupaten Karawang Tahun 2014. Jurnal Politik, 2(1), 101. https://doi.org/10.7454/jp.v2i1.83

Arjon, S. S. (2018). Religious Sentiments In Local Politics. Jurnal Politik, 3(2), 171. https://doi.org/10.7454/jp.v3i2.123

Asnawi, A., \& Madjulekka, R. (2017). Satu Daswarsa Rusdi Masse Memimpin Sidrap. Intermedia Publishing.

Creswell, J. W. (2014). Research Penelitian Kualitatif dan Desain Riset: Memilih 
Diantara Lima Pendekatan. Pustaka Pelajar.

Douglass, M. (2017). Strategic Policy Research and Action Framework for Urban Governance in Asia. November, 1-40. https://doi.org/10.13140/RG.2.2.27809.30566

Hakim, L. (2011). Pandangan Islam tentang Pluralitas dalam Konteks Kerukunan Umat Beragama Lukmanul Hakim. In Harmoni Jurnal Multikultural \& Multireligius: $\quad$ Vol. $\quad X \quad$ (Issue http://simbi.kemenag.go.id/pustaka/images/materibuku/harmoni-vol-10no-1-januari-maret.pdf\#page $=208$

Hasse, J. (2010). Kebijakan Negara Terhadap Agama Lokal “Towani Tolotang” Di Kabupaten Sidrap, Sulawesi Selatan. Journal of Government and Politics, 1(1), 145-164. https://doi.org/10.18196/jgp.2010.0009

Hasse, J. (2016). Dinamika Hubungan Islam dan Agama Lokal di Indonesia: Pengalaman Towani Tolotang di Sulawesi Selatan. Wawasan: Jurnal Ilmiah Agama Dan Sosial Budaya, 1(2), 179-186. https://doi.org/10.15575/jw.v1i2.744

Hi Manna, Z., \& Kencana Syafiie, I. (2014). Strategi Pemerintah Daerah Poso Periode 2010-2015 dalam Menghadapi Konflik Sosial. Journal of Governance and Public Policy, 1(2). https://doi.org/10.18196/jgpp.2014.0009

Hikmawati, C. L. (2017). Opresi Berlapis Perempuan Etnis Tionghoa: Pemerkosaan Massal Terhadap Perempuan Etnis Tionghoa dalam Tragedi Mei 1998 di Jakarta. Jurnal Politik, 2(2), 337. https://doi.org/10.7454/jp.v2i2.76

Jumadi. (2016). Revitalization of South Sulawesi Socio-Cultural Values Relating to Democracyin The Era of Regional Autonomy. International Journal of Social Studies (IJSS). http://eprints.unm.ac.id/1248/1/Jumadi IJSS.pdf

Kipgen, N. (2014). Addressing the Rohingya Problem. Journal of Asian and African Studies. https://doi.org/https://doi.org/10.1177/0021909613505269

Kymlicka, W. (2018). Multiculturalism: Success, Failure, and The Future, Migration Policy Institute (MPI).

Maarif, A. S. (2012). Politik Identitas dan Masa Depan Pluralisme Kita. Democracy Project.

Molan, B. (2015). Multikulturalisme: Cerdas Membangun Hidup Bersama yang Stabil dan Dinamis. Indeks.

Moleong, L. J. (2012). Metodelogi Penelitian Kualitatif (Ed). PT. Remaja Rosdakarya. Mudzhar, A. (2011). Pendekatan Studi Islam dalam Teori dan Praktek (Ed). Pustaka Pelajar.

Pulungan, J. S. (2018). Relasi Islam dan Negara: Studi Pemikiran Politik Islam dalam Perspektif al-Qur'an. Intizar, 24(1), 185-202. https://doi.org/10.19109/intizar.v24i1.2187

Qodir, Z. (2014). Radikalisme Agama di Indonesia. Pustaka Pelajar.

Rozi, S. (2013). Konstruksi Identitas Agama Dan Budaya Etnis Minangkabau Di Daerah Perbatasan: Perubahan Identitas Dalam Interaksi Antaretnis Di Rao Kabupaten Pasaman Sumatera Barat. Jurnal Masyarakat Indonesia, 39(1), 215-245. 